Louisiana State University

LSU Digital Commons

Faculty Publications

Department of Geology and Geophysics

$5-1-2010$

\title{
Palaeoenvironmental implications derived from a piston core from east lobe Bonney, Taylor Valley, Antarctica
}

\author{
Bernd Wagner \\ University of Cologne \\ Sabrina Ortlepp \\ University of Cologne \\ Fabien Kenig \\ University of Illinois at Chicago \\ Peter T. Doran \\ University of Illinois at Chicago \\ Martin Melles \\ University of Cologne
}

Follow this and additional works at: https://digitalcommons.Isu.edu/geo_pubs

\section{Recommended Citation}

Wagner, B., Ortlepp, S., Kenig, F., Doran, P., \& Melles, M. (2010). Palaeoenvironmental implications derived from a piston core from east lobe Bonney, Taylor Valley, Antarctica. Antarctic Science, 22 (5), 522-530. https://doi.org/10.1017/S0954102010000556

This Article is brought to you for free and open access by the Department of Geology and Geophysics at LSU Digital Commons. It has been accepted for inclusion in Faculty Publications by an authorized administrator of LSU Digital Commons. For more information, please contact ir@lsu.edu. 


\title{
Palaeoenvironmental implications derived from a piston core from east lobe Bonney, Taylor Valley, Antarctica
}

\author{
BERND WAGNER ${ }^{1}$, SABRINA ORTLEPP ${ }^{1}$, FABIEN KENIG ${ }^{2}$, PETER T. DORAN ${ }^{2}$ and MARTIN MELLES ${ }^{1}$ \\ ${ }^{I}$ University of Cologne, Institute of Geology and Mineralogy, Zülpicher Str: 49a, D-50674 Cologne, Germany \\ ${ }^{2}$ University of Illinois at Chicago, Earth and Environmental Sciences, M/C 186, $845 \mathrm{~W}$. Taylor St, Chicago, IL 60607-7059, USA \\ wagnerb@uni-koeln.de
}

\begin{abstract}
A $270 \mathrm{~cm}$ long sediment sequence was recovered with a piston corer from east lobe Bonney, Taylor Valley, Antarctica, and characterized according to its sedimentological, mineralogical, and geochemical properties. It is the first record of such length recovered from east lobe Bonney. The sediment core is mainly composed of halite crystals of different sizes, water, and a relatively low and stable proportion of clastic particles. Although the sediment surface was probably disturbed by the coring process and absence or low contents of organic material or carbonates hampers the establishment of a robust chronology by radiocarbon dating, the core probably contains at least several hundred years of information about the history of the lake and the Bonney basin. Variations in halite crystal sizes and amount as well as variations in the composition of clastic material can be related to past lake level changes and evaporation cycles.
\end{abstract}

Received 17 February 2010, accepted 28 June 2010, first published online 12 August 2010

Key words: evaporates, hypersaline lakes, late Holocene, palaeolimnology

\section{Introduction}

Closed basin lakes in Antarctica often exhibit a saline to hypersaline chemistry, since the inflow of ions from glacial meltwater and snowfields during summer, in combination with year-round low precipitation, high wind speeds, and high evaporation leads to ion concentration in the water column.

In Taylor Valley, one of these lakes, Lake Bonney, is characterized by hypersaline bottom waters (Figs 1 \& 2). Lake Bonney is separated into west and east lobes by a constriction of the valley, the so-called Bonney Riegel, and by a sill at $c .12 \mathrm{~m}$ water depth. The bottom waters of east and west lobe Bonney (ELB and WLB) have large differences in ionic and isotopic composition (e.g. Neumann et al. 2004, Poreda et al. 2004, Knoepfle et al. 2009) as a result of differential palaeolimnologic history during the Holocene (Poreda et al. 2004).

The late Quaternary history of the Bonney basin is in part controlled by the advance and retreat of the Taylor Glacier, which contacts WLB (Fig. 1). The Bonney drift, glacial deposits left by Taylor Glacier, indicates that the latter advanced far eastward into Taylor Valley during the Eemian and overrode and probably reshaped the Bonney basin (Higgins et al. 2000b). During the last glacial period, Taylor Glacier was in a retreated position and a large lake, Glacial Lake Washburn, occupied much of Taylor Valley (Hall et al. 2000). Glacial Lake Washburn is proglacial to an advanced Ross Sea Ice Sheet (RIS) that closed Taylor Valley mouth on the McMurdo Sound. Palaeodeltas found on the valley slopes indicate that this Glacial Lake Washburn had a maximum water depth of up to $c .300 \mathrm{~m}$.
Radiocarbon dates from these deltas indicate that Glacial Lake Washburn occupied the Bonney basin at least until c. $12000{ }^{14} \mathrm{C}$ yr BP (Hall \& Denton 2000), before enhanced evaporation and the retreat of the RIS led to a significant lake level drop during the late Pleistocene or early Holocene (Hall \& Denton 2000, Wagner et al. 2006). Since then, smaller separated lakes occupy the individual sub-basins in Taylor Valley: Lake Hoare and Lake Fryxell in the Fryxell Basin, and both lobes of Lake Bonney in the Bonney Basin (Fig. 1). In the Bonney basin, the hypersaline bottom waters of ELB carry the geochemical features of a strongly evaporated water mass with $\delta \mathrm{D}$ values well below the meteoric water line (Matsubaya et al. 1979) and very positive $\delta^{13} \mathrm{C}$ values for dissolved inorganic carbon (DIC; up to $+9 \%$ vs VPDB between 37 and $19 \mathrm{~m}$; Knoepfle et al. 2009). Such positive values for $\delta^{13} \mathrm{C}_{\mathrm{DIC}}$ were observed in strongly evaporated brine associated with deposition of evaporites (Stiller et al. 1985). It is noteworthy that bottom waters of WLB do not exhibit such an isotopic signal of evaporation. Poreda et al. (2004), on the basis of helium isotope data, proposed that rising lake level in the WLB led to flooding of the ELB during the late Holocene with a connection of both lakes at a uniform lake level, similar to that of today, c. 200 years ago.

Former studies of Lake Bonney concentrated on its hydrological, biological, biogeochemical, and physical properties, mainly within the scope of the McMurdo Long Term Ecological Research (LTER) program (e.g. Priscu 1998). Sedimentological studies of Lake Bonney are few and contradictory. Wilson et al. (1974) reported a $30 \mathrm{~cm}$ thick salt crust and Craig et al. (1974) observed that a $10 \mathrm{~cm}$ thick salt crust mainly consisting of hydrohalite and halite formed the surface sediments. 


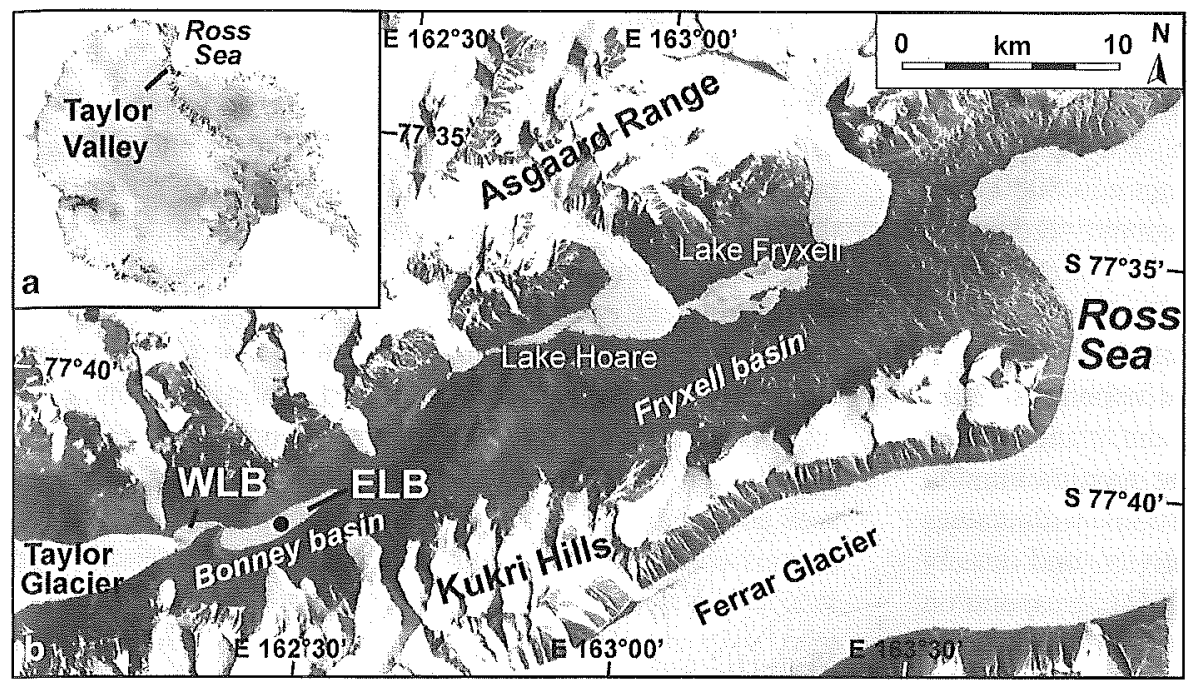

Fig. 1. a. Location of McMurdo Dry Valleys in Antarctica. b. Landsat 7 satellite image of Taylor Valley, southern Victoria Land, Antarctica (US Geological Survey 2007). The black dot in east lobe Bonney (ELB) indicates the coring location Lz1023.

During an expedition in summer 2002-03, a $270 \mathrm{~cm}$ long core (core Lz1023) was recovered from ELB. It is the longest sediment sequence so far recovered from this part of Lake Bonney. In this report we provide a detailed sedimentological characterization of core Lz1023 and discuss the palaeolimnology of ELB as constrained by this sediment record.

\section{Study site}

Lake Bonney is located in upper Taylor Valley at $57 \mathrm{~m}$ a.s.l. (Fig. 1). WLB and ELB are connected only by a narrow channel with a water depth of c. $12 \mathrm{~m}$ (Fig. 1). Both lobes are c. $900 \mathrm{~m}$ wide, but ELB at $4.8 \mathrm{~km}$ is distinctly longer than the WLB at $2.6 \mathrm{~km}$ long. The bathymetry indicates steep slopes along the length axis of both lobes, and relatively flat bottoms. The maximum water depth is c. $40 \mathrm{~m}$ in both lobes. During the past century, a lake level rise of more than $10 \mathrm{~m}$ was calculated (Chinn 1993, Bomblies et al. 2001, and own measurements during summer 2002-03). Water input into Lake Bonney originates mainly from meltwater of Taylor Glacier, but also from adjacent smaller alpine glaciers (Matsubaya et al. 1979). The perennial ice cover of both lakes has a thickness of $3.0-4.5 \mathrm{~m}$ on average (Lyons \& Welch, http://metacat.lternet.edu:8080/ $\mathrm{knb} /$ metacat?action $=$ read\&qformat $=$ mcm\&sessionid $=\&$ docid=knb-lter-mcm.62, accessed 12 December 2009).

ELB can be described as a perennial salt lake, which is hydrologically closed and chemically stratified with dense

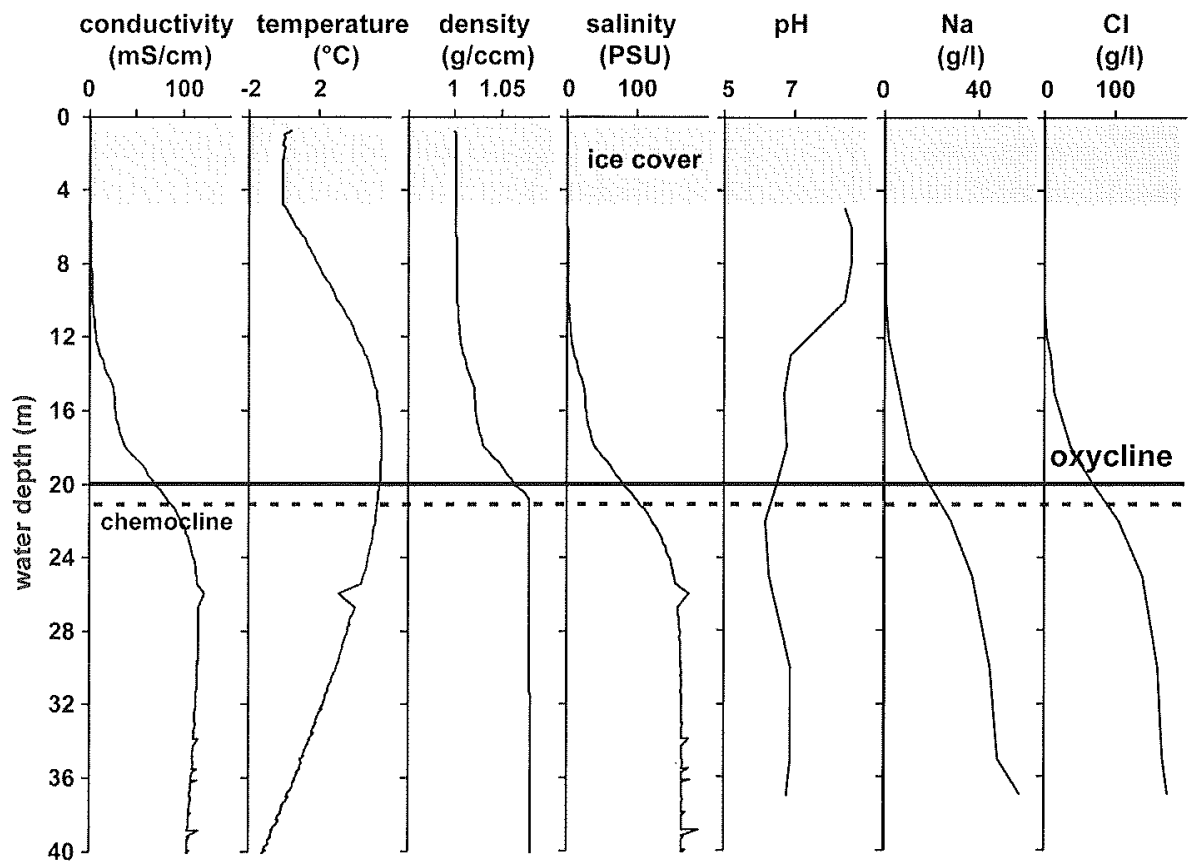

Fig. 2. Water profile of east lobe Bonney (Priscu, http://metacat. lternet.edu: $8080 / \mathrm{knb} /$ metacat? action $=$ read\&qformat $=\mathrm{mcm} \&$ sessionid $=\&$ docid $=$ knb-lter- $-\mathrm{mcm} .88$, accessed 8 July 2010; Lyons \& Welch, http://metacat.lternet.edu:8080/ $\mathrm{knb} /$ metacat?action $=$ read\&qformat $=$ $\mathrm{mcm} \&$ sessionid $=\&$ docid $=$ knb-ltermcm.62, accessed 12 December 2009). 
brine at the lake bottom overlain by fresher surface water (Eugster 1980). Water temperatures in ELB rise from c. $0^{\circ} \mathrm{C}$ below the ice cover to a maximum of nearly $5^{\circ} \mathrm{C}$ at $18 \mathrm{~m}$ depth and drop again gradually to $-1^{\circ} \mathrm{C}$ at the lake bottom (Fig. 2; Priscu, http://metacat.lternet.edu:8080/knb/ metacat? action $=$ read \&qformat $=$ mcm \&sessionid $=\&$ docid $=$ knb-lter-mcm.88, accessed 8 July 2010). A chemocline is established at c. $22 \mathrm{~m}$ water depth in ELB (Lawson et al. 2004). Above the chemocline, the input of meltwater from glaciers leads to oxygenated waters in the uppermost $20 \mathrm{~m}$ and to relatively low conductivity $\left(<4 \mathrm{mS} \mathrm{cm}^{-1}\right)$ and salinity (<4 psu) (e.g. Lawson et al. 2004). In the monimolimnion below the chemocline, hypersaline conditions with values of $>150$ psu prevail, and salinity, conductivity, and density increase towards the bottom waters (Fig. 2). Evaporation processes and cryo-concentration of freshwater have probably played an important role in the evolution of the hypersaline brine in ELB (Poreda et al. 2004). Bottom waters are supersaturated with respect to sodium chloride (Hendy et al. 1977) and mid-depth waters are supersaturated with respect to calcite (Neumann et al. 2004). The origin of these ions is still under debate. The chemical composition indicates a marine origin (e.g. Matsubaya et al. 1979). A possible source could be Blood Falls (Mikucki et al. 2009), which delivers saline and iron-rich waters into WLB from an ancient water mass beneath Taylor Glacier (Hubbard et al. 2004). However, their different chemical compositions can exclude a direct transfer of saline waters originating from Blood Falls into ELB (Mikucki et al. 2009). Other studies suggest that the saline waters in Lake Bonney originate from ancient seawater, modified over time by addition of salts from atmospheric precipitation, leaching of soils, and chemical weathering of catchment rocks (Keys \& Williams 1981), as well as by subsequent loss of solutes via mineral precipitation (Lyons et al. 2005).

\section{Material and methods}

Core Lz1023 was recovered from the central part of ELB ( $77^{\circ} 42^{\prime} 892^{\prime \prime S}, 162^{\circ} 26^{\prime} 216^{\prime \prime} \mathrm{E}$; Fig. 1), at a water depth of $38.3 \mathrm{~m}$. The coring took place through a hole in the $4.9 \mathrm{~m}$ thick ice cover. As observed by an underwater

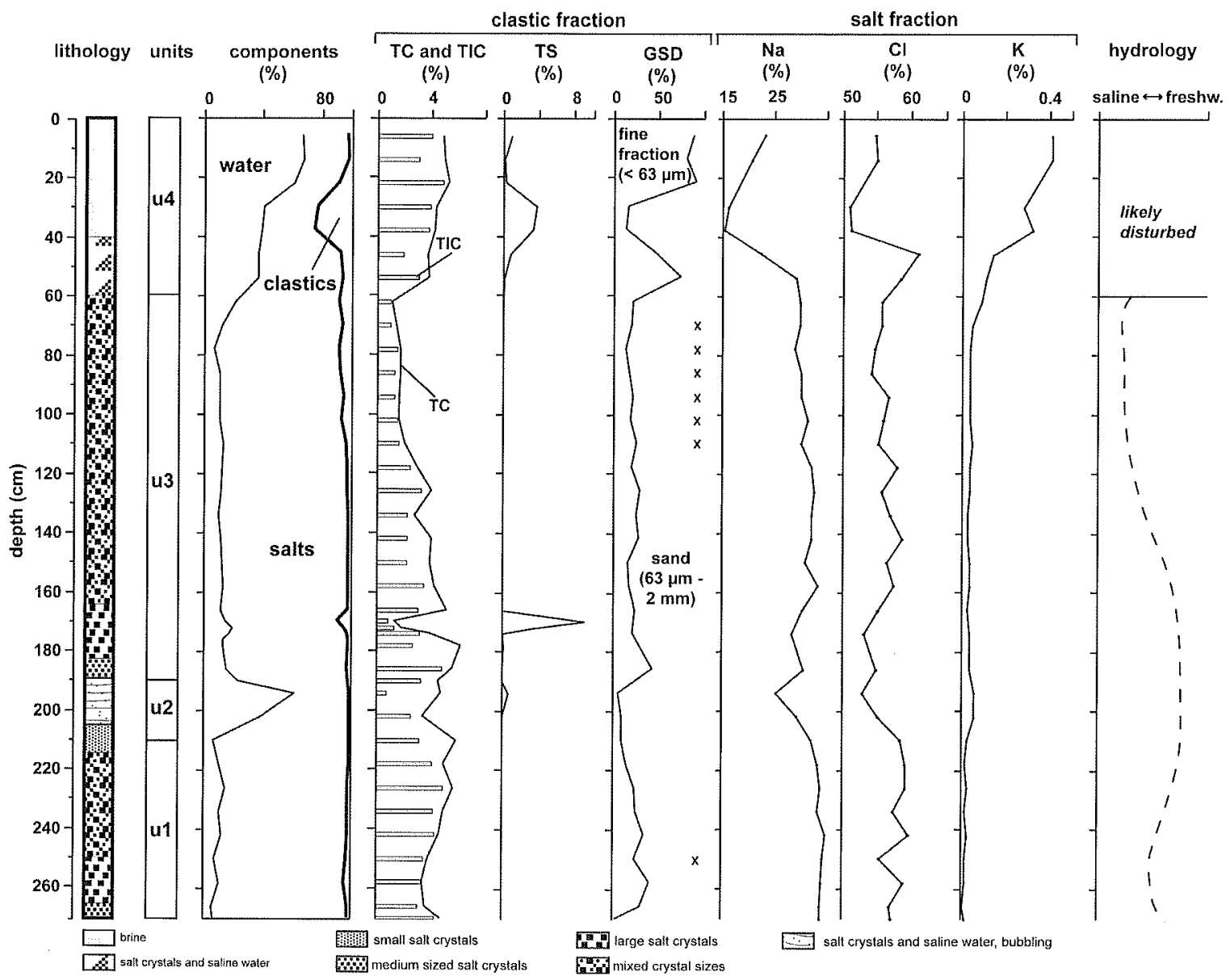

Fig. 3. Lithology, major components, total carbon (TC), total inorganic carbon (TIC), total sulphur (TS), grain size distribution (GSD), and occurrence of gravel $(>2 \mathrm{~mm}$ ) in the clastic fraction (marked by $\mathrm{x}$ ), and sodium $(\mathrm{Na})$, chloride $(\mathrm{Cl})$, and potassium (K) concentrations in the salt fraction of core $\mathrm{Lz} 1023$. 
Table I. Radiocarbon dates of carbonates from a bulk sediment sample of core Lz1023, east lobe Bonney.

\begin{tabular}{lcccccc}
\hline Sample & Core & $\begin{array}{c}\text { Depth } \\
(\mathrm{cm})\end{array}$ & Material & $\begin{array}{c}\mathrm{C} \\
(\mathrm{mg})\end{array}$ & $\begin{array}{c}\delta^{13} \mathrm{C} \\
(\% 0)\end{array}$ & $\begin{array}{c}{ }^{14} \mathrm{C} \text { age } \\
(\mathrm{yr} \mathrm{BP})\end{array}$ \\
\hline KIA 37156 & Lz1023 & $170-174$ & carbonate & 0.2 & 9.21 & $10940 \pm 100$ \\
& & carbonate & 0.9 & 6.01 & $10830 \pm 60$ \\
\hline
\end{tabular}

video camera, a hard sediment surface, apparently formed by salt crystals and sparse amounts of clastic particles, prevented penetration of a gravity corer. Consequently, an UWITEC piston corer was manually hammered into the sediment. After recovery, the piston core was placed in a dry borehole in the ice cover and immediately frozen in vertical position, using dry ice. After four hours, the core was removed from the ice hole, and the inner PVC tube containing the sediments was extracted from the outer metal tube by slowly melting the water between both tubes. The total length of core Lz1023 was determined in the field to be $259 \mathrm{~cm}$. The frozen core was cut into three segments on-site and was transported and stored frozen at $-20^{\circ} \mathrm{C}$ until processed at the University of Illinois at Chicago (USA). There, the frozen core segments were split lengthwise into two halves, photographically documented and described. One core half was again split lengthwise and one of the quarters was subsampled in contiguous $2 \mathrm{~cm}$ intervals. The water content of the subsamples was determined by the weight loss before and after freeze-drying.

The dried subsamples were diluted in deionized water and then passed through a $0.45 \mu \mathrm{m}$ filter to separate clastic material, here defined as the fraction being left on the filters. The liquid fraction, which contains the dissolved ions derived both from the salt crystals and the initial pore water, was analysed for major cations and anions. Sodium ( $\mathrm{Na}$ ) and potassium $(\mathrm{K})$ were measured by atomic adsorption spectrometry (AAS) with an AA 6800 (Shimadzu Corp), and chloride concentrations were determined using an ion chromatograph DX-120 (Dionex Corp).

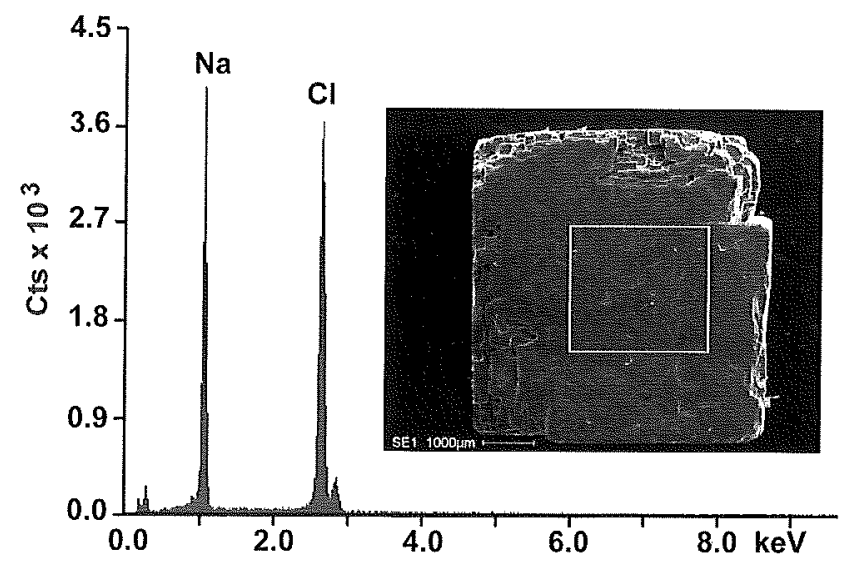

Fig. 4. Diffractogram and SEM photo of a salt crystal from $150 \mathrm{~cm}$ depth in core Lz1023.
The clastic fraction was analysed for grain-size distribution, as well as carbon and sulphur contents. As the total amount of the clastic fraction was extremely low, sporadically occurring gravel $(>2 \mathrm{~mm}$ ) would have overprinted the results and hence was removed by sieving. The grain-size distribution of the clastic fraction $<2 \mathrm{~mm}$ was measured with a laser particle size analyser 1180 (CILAS Corp). For biogeochemical analyses, an aliquot of the clastic fraction was ground to $<63 \mu \mathrm{m}$ and homogenized. Total carbon (TC) and total inorganic carbon (TIC) contents were determined with a DIMATOC 100 (DIMATEC Corp) analyzer. The total organic carbon (TOC) content was calculated by the difference between TC and TIC. The total sulphur (TS) contents were measured with an Elementar III (VARIO Corp) analyzer. Element weight percentages are related to the clastic fraction only.

Very low amounts of TIC and TOC throughout the core made radiocarbon dating difficult. A single sample from 170-174 cm depth contained sufficient TIC and was selected for accelerator mass spectrometry (AMS) dating at the Leibniz Laboratory for Radiometric Dating and Isotope Research in Kiel, Germany (Table I).

\section{Results and discussion}

\section{Stratigraphy}

In contrast to the hard sediment surface encountered during coring, the sediment surface in the core was slushy after core opening, which led to re-determination of the core length to $270 \mathrm{~cm}$. The entire sediment core is comprised of three major components: water, idiomorphic salt crystals, and a clastic fraction. According to changes in the sedimentological characteristics, core Lz1023 can be separated into four major units.

Unit 1 ranges from $270-210 \mathrm{~cm}$ (Fig. 3). It is characterized by low water contents $(10 \%)$ and a low proportion of clastic material. Energy-dispersive X-ray spectroscopy (EDAX, Fig. 4) and the results of the ion measurements (Fig. 3) indicate that the salt crystals are mainly formed by halite $(\mathrm{NaCl})$. Salt crystals vary in size throughout this unit. Medium size salt crystals with about $1 \mathrm{~cm}$ edge length are dominant between 270 and $260 \mathrm{~cm}$. Crystals with up to $2 \mathrm{~cm}$ edge length can be observed between 260 and $250 \mathrm{~cm}$ core depth. Between 250 and $220 \mathrm{~cm}$ depth, mixed crystal sizes between $1 \mathrm{~mm}$ and $1 \mathrm{~cm}$ edge length occur, and shallower than $220 \mathrm{~cm}$ depth, the individual salt crystals are barely 
visible without a microscope. The size of the crystals provides some information about the conditions during their growth. Occurrence of large crystals indicates long-term stable concentration, whilst mixed crystal sizes can be explained by changing brine conditions with contemporaneous nucleation and crystal growth (Lowenstein \& Hardie 1985). Alternating conditions of crystal growth can be caused by a variable supply of solutes and by variations in the strength of evaporation processes (Eugster 1980). However, since these processes are very complex and not completely understood, palaeoenvironmental information can only with caution be derived from the differing crystal sizes in core Lz1023. The idiomorphic shape of the cubic salt crystals (Fig. 4) suggests a slow crystallization process (King 2005).

The clastic proportion is very low throughout unit 1 . The grain size distribution is dominated by sand $(0.063-2 \mathrm{~mm})$. As high wind velocities and aeolian sand transport are common in Taylor Valley (Doran et al. 2002), the sand in unit 1 most probably results from aeolian transport. Currently, only small amounts of aeolian material are trapped in and on the ice cover of Lake Bonney. An absence of perennial ice cover, as proposed to have formerly occurred during an evaporative phase of the lake (Poreda et al. 2004), could have led to more trapping of aeolian material. A maximum in the fine fraction correlates with a slight increase in the proportion of clastic components at about $258 \mathrm{~cm}$ depth (Fig. 3). As aeolian transported material is dominated by sand and coarse silt, the maximum in the fine-grained fraction $(<0.063 \mathrm{~mm})$ can best be explained by increased meltwater inflow from glaciers. Consequently, decreasing amounts of fine-grained material and a gradually decreasing proportion of clastic components upwards could be correlated with decreasing meltwater supply to the lake and are potentially related to a cooling period with less glacier melt. Gravels $(>2 \mathrm{~mm})$ are lacking except for one horizon at c. $250 \mathrm{~cm}$ depth. Total carbon $(3.5-6 \%)$ is mainly formed by TIC and is inversely correlated to the proportion of the fine-grained fraction (Fig. 3). The TOC contents, derived from the difference between TC and TIC, apparently positively correlate with the TIC contents. The minimum in TIC and TOC contents around $c .250 \mathrm{~cm}$ in unit 1 could be due to restricted carbonate precipitation and low productivity in the lake or be due to enhanced decomposition of organic matter. However, increased amounts of reduced sulphur, which would indicate increased decomposition of organic matter (Lawson et al. 2004), are not observed throughout unit 1.

Unit 2, from $210-190 \mathrm{~cm}$ core depth, is characterized by a distinct maximum (up to $60 \%$ ) in water content (Fig. 3). This high water content is most probably related to decomposition of gas hydrates as indicated by extensive bubbling during subsampling and thawing of the core. It can however, not be fully excluded that dehydration of metastable minerals, such as the hydrated carbonate ikaite $\left(\mathrm{CaCO}_{3} \cdot 6 \mathrm{H}_{2} \mathrm{O}\right)$ or hydrated salt hydrohalite $\left(\mathrm{NaCl} \cdot 6 \mathrm{H}_{2} \mathrm{O}\right)$ may have contributed to the relatively high water contents in this unit. Both ikaite and hydrohalite are stable in the pressure (c. 5 bars) and temperature $\left(-1^{\circ} \mathrm{C}\right.$ ) conditions of the bottom of ELB (Marland 1975, Williams-Jones \& Samson 1990). However, neither ikaite nor hydrohalite are known to release gas, as we observed, when dehydrating to calcite and halite, respectively. Additionally, the relatively low abundance of TIC in unit 2 excludes ikaite as a source of the high water content. $\mathrm{Na}$ and $\mathrm{Cl}$ remain the dominating ions, but $\mathrm{K}$ shows slightly enhanced values relative to unit 1 below and unit 3 above (Fig. 3). Since the presumed gas hydrates (or metastable minerals) in this unit were decomposed and a partial dissolution of very small salt crystals may have taken place, an identification of the salt crystals in this unit cannot be given at this stage.

The very minor clastic component of unit 2 is mainly composed of sand $(0.063-2 \mathrm{~mm})$. Total carbon is between 3 and $6 \%$ by weight of the clastic fraction, but in one sample $(194 \mathrm{~cm})$, a significant amount of TOC (c. $4 \mathrm{wt} \%)$ corresponds with a small peak in TS.

Unit 3, from $190-60 \mathrm{~cm}$, is characterized by low water content (c. 10\%) and a slight increase in clastic sediments upwards. Between 80 and $60 \mathrm{~cm}$ depth, the water content increases from $c$. 10 to $20 \%$. The sizes of the salt crystals vary throughout unit 3 . Crystals with $1 \mathrm{~mm}$ to $1 \mathrm{~cm}$ edge length occur in the lower part, crystals with $1-2 \mathrm{~cm}$ edge length occur between 182 and $165 \mathrm{~cm}$, and crystals with a broad variation of edge lengths $(1 \mathrm{~mm}$ to $2 \mathrm{~cm}$ ) occur between 165 and $60 \mathrm{~cm}$. As in unit 1, these differences may have resulted from changing conditions during the growth of the salt crystals. The ion composition of the salts is similar to that of unit 1, primarily $\mathrm{Na}$ and $\mathrm{Cl}$ with a negligible amount of $\mathrm{K}$, indicating halite as the dominant mineral species.

The clastic fraction is again dominated by sand $(0.063-2 \mathrm{~mm})$. The fine fraction $(<0.063 \mathrm{~mm})$ has a slight maximum in the lower part of unit 3 and decreases in abundance upward. Gravel of up to $1 \mathrm{~cm}$ in diameter occurs between 110 and $70 \mathrm{~cm}$ depth (Fig. 3). Today, in the presence of an ice cover, grains with diameters larger than $1 \mathrm{~cm}$, mainly originating from melting icebergs or mass movement processes from the surrounding valley slopes, remain on the ice surface (Hendy 2000b). The occurrence of relatively small gravel grains at the top of unit 3 hence could be related to migration of coarse material through the ice cover or due to dropping of coarse grains through cracks in the ice cover. However, the absence of, or a very thin perennial ice cover would promote the occurrence of gravel in the sediments. The overall decrease of TC from $c$. 7 to $1 \%$ towards the top, which is caused by an overall decrease of TIC and a drop from significant amounts $(<3.5 \%)$ of TOC between 190 and $140 \mathrm{~cm}$ to negligible amounts in the upper part of this unit, can be explained either by decreasing productivity and carbonate precipitation or by increasing decomposition. A significant minimum in $\mathrm{TC}$ to $<2 \%$ at $c .170 \mathrm{~cm}$ depth corresponds with a horizon of largest $(c .2 \mathrm{~cm})$ halite crystal sizes, slightly increased amounts of clastic sediments, and 
the only distinct maximum in TS (Fig. 3). Since there is no organic matter enrichment observed along with the TS peak, this TS maximum could be due to an occurrence of gypsum crystals.

Unit 4 is the top portion of the core (Fig. 3). High water content, increasing upward, and a low salt content characterize this unit. Salt crystals of $<1 \mathrm{~mm}$ edge length occur only sparsely. The top $20 \mathrm{~cm}$ of the core exhibits a brighter colour as it contains a smaller proportion of clastic components. The ion composition shows a minimum in $\mathrm{Na}$ and $\mathrm{Cl}$ between 40 and $20 \mathrm{~cm}$ depth, which corresponds to an increase in $\mathrm{K}$ concentration (Fig. 3).

The clastic fraction in unit 4 shows a distinct increase of the fine-grained material $(<0.063 \mathrm{~mm})$ relative to lower units, except between 40 and $20 \mathrm{~cm}$, where the clastic components, dominated by sand $(0.063-2 \mathrm{~mm})$, have a distinct maximum. Total carbon, which again is mainly comprised of TIC, forms $4-6 \%$ of the clastic fraction. Total sulphur values increase between 40 and $20 \mathrm{~cm}$, where the clastic component has its maximum with up to $25 \%$ (Fig. 3).

Overall, the sedimentological characteristics of unit 4 , indicating gradual changes upwards, are not consistent with the hard and distinct sediment surface observed by means of an underwater video camera in the field. It can be speculated that hammering the piston core into the sediment broke up the hard sediment surface of ELB, and that salt crystals and clastic material became mixed with bottom water, before the core was frozen subsequent to recovery. The sediment surface/bottom water transition may have been disturbed, hampering interpretation with respect to the environmental conditions. However, unit 4 may at least partly reflect the sediment surface/bottom water transition. Previous investigations described the presence of hydrohalite $\left(\mathrm{NaCl} \cdot 2 \mathrm{H}_{2} \mathrm{O}\right)$ and halite $(\mathrm{NaCl})$ at the sediment water interface (Craig et al. 1974). Hydrohalite has a water content of 38.1\% and seems to be a primary precipitate in Lake Bonney. Since the water content between 50 and $30 \mathrm{~cm}$ depth in unit 4 is c. $40 \%$ (Fig. 3), this horizon can probably be attributed to a horizon of hydrohalite. In addition, the increased contents of TIC and TS in unit 4 are potentially related to carbonate and gypsum formation, minerals observed in prior studies of these surface sediments (Craig et al. 1974).

\section{Chronological constraints}

AMS radiocarbon dating of carbonates from $170-174 \mathrm{~cm}$ sediment depth yielded an age of $10830 \pm 60$ and $10940 \pm 100{ }^{14} \mathrm{C}$ yr BP. However, these ages have to be regarded critically. The input of old carbon derived from glacial melt and the lack of exchange with the atmosphere due to the perennial ice cover may result in a reservoir effect of up to several thousand years (Hendy \& Hall 2006), as it is common in other Antarctic lakes. Furthermore, dating was conducted on carbonates, which most probably originate from DIC in the water column. Radiocarbon dates from DIC show remarkable variations throughout the water column in ELB. Dissolved inorganic carbon ages from directly below the ice cover indicate $c .3500{ }^{14} \mathrm{C}$ yr BP (Lawson 2005). Highest radiocarbon ages of up to 13700 ${ }^{14} \mathrm{C}$ yr BP occur around the chemocline and are explained by an inflow of water from WLB, which exhibits very high DIC ages of up to c. $25000{ }^{14} \mathrm{C}$ yr вp (Neumann et al. 2004, Lawson 2005). Dissolved inorganic carbon in the bottom waters of ELB indicates radiocarbon ages of between c. 8000 and $10000{ }^{14} \mathrm{C}$ yr BP (Doran et al. 1999, Lawson 2005). As the radiocarbon ages and the related $\delta^{13} \mathrm{C}$ values in the bottom waters of ELB and the dated horizon in core Lz1023 are similar, it is probable that the dated carbonates in core Lz1023 originate from the bottom waters, as is suggested by studies of the ion composition in the bottom waters (Lyons et al. 1999). The radiocarbon dates in core Lz1023 thus only provide a maximum age for this horizon and a more precise age estimation based on the radiocarbon dates cannot be given.

Alternative age estimations are also problematic. U/Th dating of aragonites and gypsum in the surface sediments of ELB provided ages of between 1800 and $10000 \mathrm{yr}$ (Hendy et al. 1977, Hendy 2000a). Age estimations based on accumulation rates in evaporite systems provide a wide range of sedimentation rates. For example, chemical sedimentation rates of $2 \mathrm{~cm} \mathrm{yr}^{-1}$ were recorded in Freefight Lake in the Great Plains, western Canada (Last 1993) and would indicate that core Lz1023 records only about 100-150 years. On the other hand, Schreiber \& El Tabakh (2000) suggested sedimentation rates of about $0.18 \mathrm{~cm} \mathrm{yr}^{-1}$ for stratified hypersaline water bodies, which would imply that core Lz1023 records c. 1500 years. Simple calculations based on experiments (Dronkert 1985) and assuming seawater as precipitating liquid and present climate conditions with ablation rates of 150-500 $\mathrm{mm} \mathrm{yr}^{-1}$ (Clow et al. 1988) would yield ages of 400-1300 years for core Lz1023. However, a continuous formation and precipitation of salts in ELB cannot be assumed, despite relatively constant percentages of clastics throughout units 1,2, and 3. According to reconstructions based on isotopic studies, the hydrological conditions in ELB have significantly changed during the past several thousand years (Poreda et al. 2004) and precipitation and dissolution of salts as well as sedimentation breaks could have occurred.

\section{Palaeoenvironmental implications}

Absolute chronological constraints for core Lz1023 are not available. However, the relative palaeoenvironmental changes, which can be deduced from the observed variations in the sedimentological composition, can be compared with other palaeoenvironmental reconstructions from the region and thus allow a tentative age estimation for core Lz1023.

A significant accumulation of clastic particles, which could indicate evaporation events (Lowenstein \& Hardie 1985) or salt dissolution at the sediment surface in response 
to enhanced freshwater input, was not observed throughout core Lz1023. The most significant evaporation event in Taylor Valley during the late Quaternary was probably the final evaporation of Glacial Lake Washburn between c. 11000 and $8000{ }^{14} \mathrm{C}$ yr Bp (Hall \& Denton 2000, Hendy 2000a, Wagner et al. 2006). This age corresponds well with the radiocarbon ages in core Lz1023 and with the DIC in the bottom waters (Lawson 2005) and thus supports the hypotheses that the radiocarbon ages provide maximum ages and that core Lz1023 is $<10000$ years old. A Holocene age of core Lz1023 is supported by the low proportion of clastic sediments, as they were deposited in Glacial Lake Washburn (Wagner et al. 2006). Mid to late Holocene evaporation events were of minor importance and are partly restricted to the individual basins in Taylor Valley. For example, the mid to late Holocene evaporation events recorded in Lake Hoare (Lyons et al. 1998) or in Lake Fryxell (Wagner et al. 2006, Whittaker et al. 2008) do not provide a consistent age. Also the existing reconstructions of late Holocene lowstands in Lake Bonney are somewhat inconsistent. While Poreda et al. (2004) suggested a lowstand with ice-free conditions prior to $3000 \mathrm{yr}$ BP, Croall (2005) reconstructed lowstands at c. 1500, 800 and $400 \mathrm{yr}$ вp. None of these events apparently was significant enough to become recorded as a distinct clastic layer in ELB. The overall sedimentary characteristics, however, imply that distinct environmental changes are recorded in core Lz1023.

The occurrence of gravel in units 1 and 3 could be due to a non-perennial ice cover, and hence most probably more saline conditions, as they exist today in ELB. More saline conditions around $250 \mathrm{~cm}$ and between $c .120$ and $65 \mathrm{~cm}$ depth in core Lz1023 are supported by relatively large salt crystal sizes, which indicate relatively stable environmental conditions. In contrast, the sediments between 230 and $150 \mathrm{~cm}$ indicate no occurrence of gravel. Moreover, this horizon is characterized by increased contents of TOC and $\mathrm{TIC}$ and a slight minimum in $\mathrm{Na}$ and $\mathrm{Cl}$ ions. These characteristics imply more freshwater conditions, a stratified water column, a permanent ice cover, but also slightly increased productivity and carbonate precipitation. Distinctly changing salt crystal sizes in this horizon indicate unstable environmental conditions. The minimum in salt crystal sizes around $200 \mathrm{~cm}$ (Fig. 3) is probably the result of high nucleation and these unstable environmental conditions. A freshening of ELB waters could originate from enhanced meltwater inflow from local sources, such as minor alpine glaciers, or from freshwater overflow from the WLB into the ELB (Poreda et al. 2004). This could have occurred during the so-called Alpine I drift, when Taylor Glacier and alpine glaciers advanced and reached maximum positions younger than $2500-3500{ }^{14} \mathrm{C}$ yr BP (Hall \& Denton 2000, Higgins et al. 2000a). Lake Fryxell exhibited a relatively high lake level between 3000 and $2000 \mathrm{yr}$ BP (Whittaker et al. 2008), which was probably supported by a humid climate during this period (Smith \& Friedman 1993). The sediments between
230 and $150 \mathrm{~cm}$ depth in core Lz1023 from ELB could have been deposited around the same period, implying that the period after c. 2000 yr BP was characterized by more saline conditions (Fig. 3). This would at least partly match with lake level reconstructions of ELB based on helium isotope data, which indicate saline to hypersaline conditions and a nonperennial ice cover sometime between c. 3000 and $200 \mathrm{yr}$ BP (Poreda et al. 2004). Given the uncertainty in chronology in core Lz1023, these correlations remain speculative.

It can also only be speculated about the most recent history of ELB, since the sediment surface in core Lz1023 appears to have been disturbed by the coring. Enhanced freshwater inflow into ELB, which is confirmed by diffusion processes occurring higher in the water column today (Spigel \& Priscu 1996) and by the rising lake level during the last century (Chinn 1993, Barrett et al. 2008), and the establishment of a permanent ice cover during the past 200 years (Poreda et al. 2004) might explain the occurrence of carbonates and gypsum, such as indicated in unit 4 and observed in other surface sediment studies from ELB (Craig et al. 1974, Hendy et al. 1977). It cannot be excluded that the enhanced freshwater input led to equilibrium between precipitation and dissolution and that precipitation of halite from the brine is currently interrupted. Interruption of halite precipitation would probably lead to a higher proportion of clastic material, if sedimentation of clastic material remains relatively constant. The maximum of clastic material in unit 4 would support such a scenario.

\section{Conclusions}

Core Lz1023 from ELB shows for the first time that idiomorphic halite crystals of different sizes form at least the uppermost $2.1 \mathrm{~m}$ of sediments. Other evaporites, such as gypsum or aragonite, appear to occur in few horizons, but may have been disturbed particularly at the sediment surface by the coring process. An overall very low and relatively stable proportion of clastic material, i.e. minerals and organic matter that were not water soluble, implies that major desiccation events or dissolution events were lacking throughout the period recovered in core Lz1023. However, the occurrence of gravel at the core base and in the top part of the core implies more saline conditions, as they exist today. The interspersed horizon with no occurrence of gravel, relatively high contents of TOC and TIC, a minimum in $\mathrm{Na}$ and $\mathrm{Cl}$ ion concentration and relatively small salt crystal sizes implies more freshwater conditions. These conditions are described to have occurred probably younger than 2000-3000 years ago in the region, but may have also occurred between two lake level lowstands, as they are reported from Lake Bonney at 800 and 400 years ago. The exact chronology of core Lz1023 has to remain open at this stage, since the low contents of carbon hamper radiocarbon dating and age estimations based on evaporite sedimentation rates yield high uncertainties. 


\section{Acknowledgements}

The project was funded by the Deutsche Forschungsgemeinschaft (DFG, Me 1169/4-1) and by the National Science Foundation (OPP 0096250, 0126270). Peter Glenday, Jennifer Lawson Knoepfle, and David Mazzucchi are thanked for their assistance in the field. Brenda Hall, Berry Lyons and Alan Vaughan are thanked for numerous comments and suggestions on the manuscript.

\section{References}

Barrett, J.E., Virginia, R.A., Wall, D.H., Doran, P.T., Fountain, A.G., WELCH, K.A. \& LYONS, W.B. 2008. Persistent effects of a discrete warming event on a polar desert ecosystem. Global Change Biology, 14, 2249-2261

Bomblies, A., McKnight, D.M. \& Andrews, E.D. 2001. Retrospective simulation of lake-level rise in Lake Bonney based on recent 21 -year record: indication of recent climate change in the McMurdo Dry Valleys, Antarctica. Journal of Paleolimnology, 25, 477-492.

Chinn, T.J. 1993. Physical hydrology of the dry valley lakes. Antarctic Research Series, 59, 1-51.

Clow, G.D., McKay, C.P., Simmons JR, G.M. \& Wharton Jr, R.A. 1988. Climatological observations and predicted sublimation rates at Lake Hoare, Antarctica. Journal of Climate, 1, 715-728.

Craig, J.R., Fortner, R.D. \& Weand, B.L. 1974. Halite and hydrohalite from Lake Bonney, Taylor Valley, Antarctica. Geology, 1, 389-390.

Croall, J.G. 2005. Late Holocene cool climate episodes recorded in Lake Bonney, an Antarctic amplifier lake. MSc thesis, University of Waikato, 177 pp. [Unpublished.]

Doran, P.T., Berger, G.W., Lyons, W.B., Wharton Jr, R.A., Davisson, M.L., Southon, J. \& Diвb, J.E. 1999. Dating Quaternary lacustrine sediments in the McMurdo Dry Valleys, Antarctica. Palaeogeography, Palaeoclimatology, Palaeoecology, 147, 223-239.

Doran, P.T., McKay, C.P., Clow, G.D., Dana, G.L., Fountain, A.G., NyLEN, T. \& Lyons, W.B. 2002. Valley floor climate observations from the McMurdo Dry Valleys, Antarctica, 1986-2000. Journal of Geophysical Research, 107, 10.1029/2001JD002045.

DronkERT, H. 1985. Evaporite models and sedimentology of Messinian and recent evaporites. $\mathrm{PhD}$ thesis, Universiteit van Amsterdam, $283 \mathrm{pp}$. [Unpublished.]

Eugster, H.P. 1980. Geochemistry of evaporitic lacustrine deposits. Annual Review of Earth and Planetary Sciences, 8, 35-63.

Hall, B.L. \& Denton, G.H. 2000. Radiocarbon chronology of Ross Sea Drift, eastern Taylor Valley, Antarctica: evidence for a grounded ice sheet in the Ross Sea at the Last Glacial Maximum. Geografiska Annaler, 82A, 305-336.

Hall, B.L., Denton, G.H. \& Hendy, C.H. 2000. Evidence from Taylor Valley for a grounded ice sheet in the Ross Sea, Antarctica. Geografiska Annaler, 82A, 275-303.

Hendy, C.H. 2000a. Late Quaternary lakes in the McMurdo Sound region of Antarctica. Geografiska Annaler, 82A, 411-432.

Hendy, C.H. 2000b. The role of polar lake ice as a filter for glacial lacustrine sediments. Geografiska Annaler, 82A, 271-274.

Hendy, C.H. \& HaLl, B. 2006. The radiocarbon reservoir effect in proglacial lakes: examples from Antarctica. Earth and Planetary Science Letters, 241, 413-421.

Hendy, C.H., Wilson, A.T., Popplewell, K.B. \& House, D.A. 1977. Dating of geochemical events in Lake Bonney, Antarctica, and their relation to glacial and climate changes. New Zealand Journal of Geology and Geophysics, 20, 1103-1122.

Higgins, S.M., Denton, G.H. \& Hendy, C.H. 2000a. Glacial geomorphology of Bomey Drift, Taylor Valley. Geografiska Annaler, 82A, 365-390.
Higgins, S.M., Hendy, C.H. \& Denton, G.H. 2000b. Geochronology of Bonney Drift, Taylor Valley, Antarctica: evidence for interglacial expansions of Taylor Glacier. Geografiska Annaler, 82A, 391-409.

Hubbard, A., Lawson, W., Anderson, B., Hubbard, B.P. \& Blatter, H. 2004. Evidence for subglacial ponding across Taylor Glacier, Dry Valleys, Antarctica. Annals of Glaciology, 39, 79-84.

KEYS, J.R. \& WiLluams, K. 1981. Origin of crystalline, cold desert salts in the McMurdo region, Antarctica. Geochimica et Cosmochimica Acta, 45, 2299-2309.

KING, R.J. 2005. Minerals explained 42: Halite. Geology Today, 21, 153-157. Knoepfle, J.L., Doran, P.T., Kenig, F., Lyons, W.B. \& Galchenko, V.F. 2009. Particulate organic and dissolved inorganic carbon stable isotopic compositions in Taylor Valley lakes, Antarctica: the effect of legacy. Hydrobiologia, 632, 139-156.

LAST, W.M. 1993. Rates of sediment deposition in a hypersaline lake in the northern Great Plains of western Canada. International Journal of Salt Lake Research, 2, 47-58.

LAWSON, J.L. 2005. Lacustrine biogeochemistry of the McMurdo Dry Valleys, Antarctica. MSc thesis, University of Illinois at Chicago, 173 pp. [Unpublished.]

Lawson, J.L., Doran, P.T., Kenig, F., des Marais, D.J. \& Priscu, J.C. 2004. Stable carbon and nitrogen isotopic composition of benthic and pelagic organic matter in lakes of the McMurdo Dry Valleys, Antarctica. Aquatic Geochemistyy, 10, 269-301.

Lowenstein, T.K. \& Hardie, L.A. 1985. Criteria for the recognition of saltpan evaporites. Sedimentology, 32, 627-644.

Lyons, W.B., FrAPE, S.K. \& Welch, K.A. 1999. History of McMurdo Dry Valley lakes, Antarctica, from stable chlorine isotope data. Geology, 27, 527-530.

Lyons, W.B., Tyler, S.W., Wharton, R.A., McKnight, D.M. \& Vaughin, B.H. 1998. A late Holocene desiccation of Lake Hoare and Lake Fryxell, McMurdo Dry Valleys, Antarctica. Antarctic Science, 10, 247-256.

Lyons, W.B., Welch, K.A., Snyder, G., Olesik, J., Graham, E.Y., Marion, G.M. \& PoREDA, R.J. 2005. Halogen geochemistry of the McMurdo Dry Valleys lakes, Antarctica: clues to the origin of solutes and lake evolution. Geochimica et Cosmochimica Acta, 69, 305-323.

Marland, G. 1975. The stability of $\mathrm{CaCO}_{3} \cdot 6 \mathrm{H}_{2} \mathrm{O}$ (ikaite). Geochimica et Cosmochimica Acta, 39, 83-91.

Matsubaya, O., Sakal, H., Toril, T., Burton, H. \& Kerry, K. 1979. Antarctic saline lakes: stable isotopic ratios, chemical compositions and evolution. Geochimica et Cosmochimica Acta, 43, 7-25.

Mikucki, J.A., Pearson, A., Johnston, D.T., Turchyn, A.V., Farquhar, J., Schrag, D.P., Anbar, A.D., Priscu, J.C. \& Lee, P.A. 2009. A contemporary microbially maintained subglacial ferrous "ocean". Science, 324, 397-400.

Neumann, K., Lyons, W.B., Priscu, J.C., des Marais, D.J. \& Welch, K.A. 2004. The carbon isotopic composition of dissolved inorganic carbon in perennially ice-covered Antarctic lakes: searching for a biogenic signature. Annals of Glaciology, 39, 518-524.

Poreda, R.J., Hunt, A.G., Lvons, W.B. \& Welch, K.A. 2004. The helium isotopic chemistry of Lake Bonney, Taylor Valley, Antarctica: timing of late Holocene climate change in Antarctica. Aquatic Geochemistry, 10, 353-371.

Priscu, J.C., ed. 1998. Ecosystem dynamics in a polar desert: the McMurdo Dry Valleys, Antarctica. Antarctic Research Series, 72, 369 pp.

Schreiber, B.C. \& El TABakh, M. 2000. Deposition and early alteration of evaporites. Sedimentology, 47, 215-238.

Smith, G.I. \& Friedman, I. 1993. Lithology and paleoclimatic implications of lacustrine deposits around Lake Vanda and Don Juan Pond, Antarctica. Antarctic Research Series, 59, 83-94.

SPIGEL, R.H. \& Priscu, J.C. 1996. Evolution of temperature and salt structure of Lake Bonney, a chemically stratified Antarctic lake Hydrobiologia, 321, 177-190.

Stiller, M., Rounick, J.S. \& Shasha, S. 1985. Extreme carbon-isotope enrichments in evaporite brines. Nature, 316, 434-435. 
Wagner, B., Melles, M., Doran, P.T., Kenig, F., Forman, S.L., Pierau, R. \& Allen, P. 2006. Glacial and postglacial sedimentation in the Fryxell basin, Taylor Valley, southern Victoria Land, Antarctica. Palaeogeography, Palaeoclimatology, Palaeoecology, 241, 320-337.

Whittaker, T.E., Hall, B.L., Hendy, C.H. \& Spaulding, S.A. 2008. Holocene depositional environments and surface-level changes at Lake Fryxell, Antarctica. The Holocene, 18, 775-786.
Williams-Jones, A.E. \& SAmson, I.M. 1990. Theoretical estimation of halite solubility in the system $\mathrm{NaCl}-\mathrm{CaCl}_{2}-\mathrm{H}_{2} \mathrm{O}$ : applications to fluid inclusions. Canadian Mineralogist, 28, 299-304.

Wilson, A.T., Hendy, C.H., Healy, T.R., Gumbley, J.W., Field, A.B. \& ReYNolds, C.P. 1974. Dry valley lake sediments: a record of Cenozoic climatic events. Antarctic Journal of the United States, 9(4), $134-135$. 


\section{CONTENTS}

Editorial

461

\section{BIOLOGICAL SCIENCES}

Small-scale studies towards a rational use of bioaugmentation in an Antarctic hydrocarbon-contaminated soil Lucas Ruberto, Susana C. Vazquez, Romina L. Dias, Edgardo A. Hernández, Silvia H. Coria, Gustavo Levin, Alfredo lo Balbo \& Walter P. MaC CORMack

Viable microbes in ice: application of molecular assays to McMurdo Dry Valley lake ice communities Markus Dieser, ANDreas NoCKer, John C. Priscu \& CHRISTINE M. FOREMAN

Reference genes validation for qPCR normalization in Deschampsia antarctica during abiotic stresses Hyoungseok Lee, Ji Hyun Kim, Mira Park, Il-Chan Kim, Joung HaN Yim \& Hong Kum LeE

Impact of expected global warming on $\mathrm{C}$ mineralization in maritime Antarctic soils: results of laboratory experiments

Juliana Vanir de Souza Carvalho,

Eduardo de Sá Mendonça, Rui Tarcísio Barbosa,

Efrain Lázaro Reis, Paulo Negrais Seabra \&

Carlos ERnesto G.R. Schaefer

Antitumoural activity in Antarctic and sub-Antarctic benthic organisms

Sergi Taboada, Luis Francisco García-Fernández, Santiago Bueno, Jennifer VAzquez, Carmen Cuevas \& CONXITA AVILA

The establishment of a new ecological guild of pollinating insects on sub-Antarctic Soưth Georgia

P. CONVEY, R.S. KEY \& R.J.D. KEY

\section{EARTH SCIENCES}

Post 3.9 Ma fault activity within the West Antarctic rift system: onshore evidence from Gandalf Ridge, Mount Morning eruptive centre, southern Victoria Land, Antarctica AdAM P. MARTin \& Alan F. COOPER

Palaeoenvironmental implications derived from a piston core from east lobe Bonney, Taylor Valley, Antarctica Bernd Wagner, Sabrina ORTLEPP, Fabien Kenig, Peter T. Doran \& Martin Melles

Short Note: New fossil turtle remains from the Eocene of the Antarctic Peninsula

Paula Bona, Marcelo S. de la Fuente \& MARCELo A. REguero

\section{PHYSICAL SCIENCES}

Mean circulation and hydrography in the Ross Sea sector, Southern Ocean: representation in numerical models GraHAm J. Rickard, Malcolm J. RoBerts, Michael J.M. Williams, Alistair DunN \& MurRay H. SMith

The Pacific zonal asymmetry and its influence on Southern Hemisphere sea ice variability W.R. HoBbS \& M.N. RAPHAEL

Seismological constraints on ice properties at Dome C, Antarctica, from horizontal to vertical spectral ratios Jean-Jacques Lévêque, Alessia Maggi \& Annie Souriau

Potential source regions of biogenic aerosol number concentration apportioning at King George Island, Antarctic Peninsula

AlEXANDRE S. AlenCAR, Heitor EVANGELista, Elaine A. Dos Santos, Sergio M. Correa, Myriam Khodri, Virginia M.T. Garcia, Carlos A.E. Garcia, Enio B. Pereira, Alberto R. Piola \& ISRAEL FELZENSZWALB

Antarctic Science is abstracted in Current Contents, SciSearch, Research Alert, Geo Abstracts, Current Awareness in Biological Sciences, Mineralogical Abstracts, Meteorological \& Geo-astrophysical Abstracts, Current Antarctic Literature, GeoArchive, GeoRef, Biosis, Oceanographic Literature, Environmental Periodicals Bibliography and Polar \& Glaciological Abstracts

\section{Cambridge Journals Online} For further information about this journal please go to the journal website at: journals.cambridge.org/ans

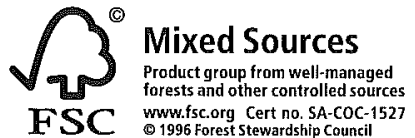

Product group from well-managed
forests and other controlled sources www.fsc.org Cert no. SA-COC-1527

\section{CAMBRIDGE} UNIVERSITY PRESS 